\title{
Frequency of Specific anti-Toxoplasma gondii IgM, IgA and IgE in Colombian Patients with Acute and Chronic Ocular Toxoplasmosis
}

\author{
Jorge Enrique Gómez-Marín*/+, Maria Teresa Montoya-de-Londoño**, \\ Jhon Carlos Castaño-Osorio**, Fernando Alvarado Heine*, Ana Maria Duque***, \\ Cathy Chemla, Dominique Aubert, Annie Bonhomme, Jean Michel Pinon
}

\begin{abstract}
Laboratoire de Parasitologie Mycologie, IFR 53, EA 2070, Faculté de Médecine, Université de Reims Champagne-Ardenne, CHU, 51096 Reims, France *Unidad de Infectologia y Unidad de Parasitologia, Facultad de Medicina, Universidad Nacional de Colombia, Santafé de Bogota D.C., Colombia **Centro de Investigaciones

"Manuel Elkin Patarroyo", Facultad de Medicina, Universidad del Quindio, Armenia (Quindio), Colombia ***Departmento de Oftalmologia, Hospital "La Misericordia" Calarca (Quindio), Colombia
\end{abstract}

We studied the frequency of specific anti-Toxoplasma $\operatorname{IgM}, \operatorname{IgA}$ and $\operatorname{IgE}$ antibodies in serum of 28 immunocompetent Colombian patients, selected by ophthalmologists and with lesions that were compatible with ocular toxoplasmosis. Patients were classified in three groups: (i) group 1 consisted of ten patients with a first episode; (ii) group 2, with seven patients with a recurrence and (iii) group 3, consisted of eleven patients with chronic chorioretinal lesion without uveitis. We found that 10/28(35\%) of Colombian patients with ocular toxoplasmosis possessed at least one serological marker for Toxoplasma infection different from IgG. In group 1 (first episode), we found simultaneous presence of specific IgM plus IgA plus IgE in 1/10 (10\%). In group 2 (recurrences) in 1/7 (14\%) we found IgM and IgA test positives and in 1/7 (14\%) we found IgM and IgE tests positives. In group 3 (toxoplasmic chorioretinal scar) the IgA serological test was positive in 2/11 (18\%). These results show that serum IgM or IgA or IgE can be present during recurrences.

Key words: toxoplasmosis - human ocular toxoplasmosis - IgG - IgM - IgA - IgE

Ocular toxoplasmosis is one of the main clinical manifestations of the human infection by the protozoan parasite Toxoplasma gondii (Remington et al. 1995). The retina is the primary site of $T$. gondii infection in the eye (Holland et al. 1996). The lesions cause retinal scars and the loss of visual function when the macula region is involved. Once a scar is established it remains for the whole life; recurrence lesions around scars are common

\footnotetext{
This work was supported by the Research Fund of the University of Quindio (Colombia) and by the Programme Hospitalier de Recherche Clinique, Direction des Hôpitaux, Ministère des Affaires Sociales de la Santé et de la Ville (France). Part of this work was realized during a scientific visit of MT Montoya to the laboratory of Parasitology in Reims, supported by the researcher's formation program of BID-Colciencias (Colombia). ${ }^{+}$Corresponding author. Supported by a doctoral fellowship from Colciencias (Colombia). Present address: Instituto de Salud en el Trópico, Facultad de Medicina, Universidad Nacional de Colombia, Santafé de Bogota D.C., Colombia. Fax: 57-1-3681486. E-mail: jegomez@cable.net.co Received 23 February 1999 Accepted 11 November 1999
}

and can aggravate the visual deficiency (Holland et al. 1996). Toxoplasmic chorioretinitis has been found to be the most common recognizable cause of posterior uveitis (intraocular inflammatory syndrome) in many surveys (Henderly et al. 1987). In a recent study in Dutch patients, toxoplasmic uveitis was the most frequent cause of unilateral visual loss (Rothova et al. 1996). In Colombia, ocular toxoplasmosis represents $4 \%$ of consultation in ophthalmology (Varela 1986). The ocular involvement of toxoplasmosis has been considered a recurrent manifestation of congenital infection. However, for many years an infrequently reported, but important, subgroup of patients was that with toxoplasmic chorioretinitis as the only manifestation of recently acquired toxoplasmosis. Recent reports show that this form of presentation in non-immunosuppressed patients is more common than believed (Nussenblatt \& Belfort 1994, Ronday et al. 1995). Montoya and Remington (1996) reported 22 adult cases with serological profile presumptive of acute acquired toxoplasmosis. Such patients had detectable IgM antibodies and/or acute pattern by a differential agglutination test but did not have lymphadenopathy or other nonocular clinical disease. Most of these patients were non-im- 
munosuppressed, however the authors did not include chronic toxoplasmic chorioretinitis without inflammatory signs. We report here the frequency of $\operatorname{IgM}, \operatorname{IgA}$ and $\operatorname{IgE}$ specific anti-T. gondii antibodies in sera of Colombian patients with toxoplasmic chorioretinitis during the acute symptomatic setting (first episode or recurrence) and during the non-inflammatory status.

\section{MATERIALS AND METHODS}

Patients - We performed serological studies in consecutively non-immunosuppressed Colombian patients with ocular toxoplasmosis referred by opthalmologists during the period of June to September 1994 and March to June 1996. The patients presented retinal inflammatory lesions consistent with ocular toxoplasmosis and diagnosis was made using the criteria defined previously (Holland et al. 1996). The patients were asked about similar episodes and classified according to their clinical ocular history and the result of ofthalmoscopic examination. Group 1 consisted of ten patients with signs of vitritis and a first episode (established by history) and without old retinal scars at examination. Group 2 consisted of seven patients with recurrence, they had signs of vitritis and history of a least one similar past episode or the presence of retinal scars indicating past episodes. Group 3 consisted of eleven patients with old scars and without retinal inflammatory signs at the moment of sampling. These former patients were discovered in a prevalence study of ocular toxoplasmosis in the Quindio region performed during January-August 1996. All patients were originating from the Quindio region (central Andean area of Colombia). The collection of clinical data was made by a questionnaire including clinical and epidemiological antecedents. All patients were asked about extra-ocular clinical manifestations and were also examined looking for extraocular signs.

Serological studies - All studied patients were positive for specific IgG anti- $T$. gondii by immunofluorescence antibody test (IFAT-IgG) (Instituto Nacional de Salud 1981). Briefly, the formaldehyde-treated tachyzoites obtained from peritoneal exudate of mice was fixed on glass slides. Two fold dilutions of serum samples were incubated $1 \mathrm{hr}$ and washed twice with $150 \mathrm{mM}$ phosphate buffer $(\mathrm{pH}$ 7.2) and then incubated with a fluorescein isothiocyanate-conjugated secondary antibody (Fluoline H, Biomérieux) diluted 1:320. The IFATIgG result was considered to be reactive when fluorescence of the entire parasite appeared at dilution of 1:8. Frenkel (1990) noted that dilutions of 1:8 can be useful in old infection as can occurs in ocular toxoplasmosis and that cross reactions with infections by others Coccidia can be considered minimal in humans. Specific $\operatorname{IgM}, \operatorname{IgA}$ and $\operatorname{IgE}$ anti-T. gondii antibodies were studied by immunocapture assay (IC) as described previously (Pinon et al. 1995) and performed in the laboratory of "Hôpital Maison Blanche" in Reims (France). Briefly, each serum sample was diluted (1:100) and deposited in three adjacent wells of microplates sensitized with anti-IgM, anti-IgA or anti-IgE monoclonal antibodies. The plates were then incubated for 2.5 hr. After the plates were washed with $150 \mathrm{mM}$ phosphate buffer ( $\mathrm{pH}$ 7.2), a suspension of formaldehyde-treated tachyzoites was added at concentration of 1, 1.5 and 2 million parasites to the three wells respectively. Sedimentation was read by an automated system with specific software and the results expressed in points from 0 to 12 according to end-point agglutination (Pinon et al. 1995). The following results were considered positive in the IC assay: 9 points for specific IgM, 4 points for specific $\operatorname{IgA}$ and 1 point for $\operatorname{IgE}$.

\section{RESULTS}

The clinical data are summarized in Tables I, II and III. The mean age in group 1 was 27.9 years (range 11-57), in group 2 was 32.2 years (range 25-45) and in group 3 was 33.5 years (range 19$54)$. The distribution by sex was $60 \%(6 / 10)$ of males in group $1,14.2 \%(1 / 7)$ in group 2 and $36 \%$ $(4 / 11)$ in group 3. Serological results are shown in Table IV, V and VI. We found that chronic and acute ocular toxoplasmosis in 10/28 (35\%) of Colombian non-immunosuppressed patients was accompanied by serological markers others than specific IgG. More interesting, one patient (patient no. 7) aged 57 years-old and with a first episode presented specific anti- $T$. gondii IgM plus IgA plus $\operatorname{IgE}$ positives test (IgM 12, IgA 12, IgE 1) strongly indicating a recent acquired infection and not recurrence of a congenital infection. In one patient (patient no. 15) with a recurrence (the first episode was two years before) we found the IgM and IgA positive tests, but the IgE test was negative. In another patient (patient no. 11) with recurrence IgM and $\operatorname{IgE}$ test were positives. In patients from the group without inflammatory signs two of them (patients nos. 22 and 23) were IgA positive without high IgG titers ( $<1 / 128$ by IFAT technique) and none of them had IgM or IgE positive tests.

\section{DISCUSSION}

The only reliable way to ascertain a recently acquired $T$. gondii infection by serological tests is by documenting seroconversion. However, this finding can be difficult to make when a patient visits the ophthalmologist weeks or months after $T$. gondii infection. An alternative strategy to distinguish a recently acquired from a congenitally acquired ocular toxoplasmosis is by measuring $T$. gondii-specific immunoglobulins (other than IgG) like IgM, IgA or 
TABLE I

Clinical findings and outcome for ten Colombian patients with a first episode of ocular toxoplasmosis

\begin{tabular}{|c|c|c|c|c|c|c|c|c|c|}
\hline $\begin{array}{l}\text { Patient } \\
\text { no. }\end{array}$ & Sex & Age & $\begin{array}{c}\text { Eye (s) } \\
\text { involved }\end{array}$ & Localization of lesion & $\begin{array}{c}\text { Visual } \\
\text { acuity at } \\
\text { sampling }\end{array}$ & $\begin{array}{l}\text { Visual acuity } \\
\text { at end of episode } \\
\text { and complications }\end{array}$ & $\begin{array}{l}\text { Duration of uveitis at } \\
\text { the time of sampling }\end{array}$ & $\begin{array}{l}\text { Extra-ocular } \\
\text { symptoms }\end{array}$ & Treatment \\
\hline 1. & $\mathrm{M}$ & 11 & $\mathrm{~L}$ & Vitritis & $20 / 80$ & $20 / 20$ & 6 days & No & Cstd. \\
\hline 2. & M & 19 & $\mathrm{~L}$ & Vitritis & $20 / 70$ at $2 \mathrm{~m}$ & $\begin{array}{c}20 / 70 \text { at } 3 \mathrm{~m} \\
\text { Persistent vitritis }\end{array}$ & 30 days & No & Cstd. + P-S \\
\hline 3. & $\mathrm{~F}$ & 24 & $\mathrm{R}$ & Peripherical chorioret. & $20 / 20$ & $20 / 20$ & 5 months & No & None \\
\hline 4. & M & 26 & $\mathrm{R}$ & Vitritis & $20 / 200$ & $\begin{array}{c}\text { Only ligth } \\
\text { Persistent vitritis }\end{array}$ & 3 months & No & Cst. \\
\hline 5. & M & 45 & $\mathrm{~L}$ & Peripapilar chorioret. & $20 / 20$ & $20 / 20$ & 3 months & No & None \\
\hline 6. & $\mathrm{~F}$ & 54 & R-L & $\begin{array}{l}\mathrm{R} \text { : macular chorioret. } \\
\mathrm{L} \text { : macularchorioret. }\end{array}$ & $\begin{array}{l}\text { R 20/200 } \\
\text { L 20/400 }\end{array}$ & $\begin{array}{l}\mathrm{R}: 20 / 200 \\
\mathrm{~L}: 20 / 400\end{array}$ & 2 months & No & None \\
\hline 7. & M & 57 & $\mathrm{R}$ & Vitritis & $20 / 80$ & $\begin{array}{l}20 / 40 \\
\text { Persistent vitritis }\end{array}$ & 20 days & No & Cstd. \\
\hline 8. & $\mathrm{~F}$ & 12 & $\mathrm{~L}$ & Macular chorioret. & $\mathrm{CF}$ at $3 \mathrm{~m}$ & $\mathrm{CF}$ at $3 \mathrm{~m}$ & 40 days & No & Cst. + P-S. \\
\hline 9. & $\mathrm{~F}$ & 11 & $\mathrm{R}$ & Vitritis & $20 / 200$ & $20 / 200$ & 45 days & No & Cstd. \\
\hline 10. & $\mathrm{M}$ & 20 & $\mathrm{R}$ & Peripherical chorioret. & $20 / 30$ & $20 / 30$ & 30 days & No & Cstd + P.S. \\
\hline
\end{tabular}

M: male; F: female; R: right; L: left; CF: counting fingers; Chorioret.: chorioretinitis; Cstd.: corticosteroids; P-S: pyrimethamine-sulfadoxine; severity score: normal 20/20, moderate: 20/30-20/100, severe $>$ or $=20 / 200$ (Snell's visual acuity table). 


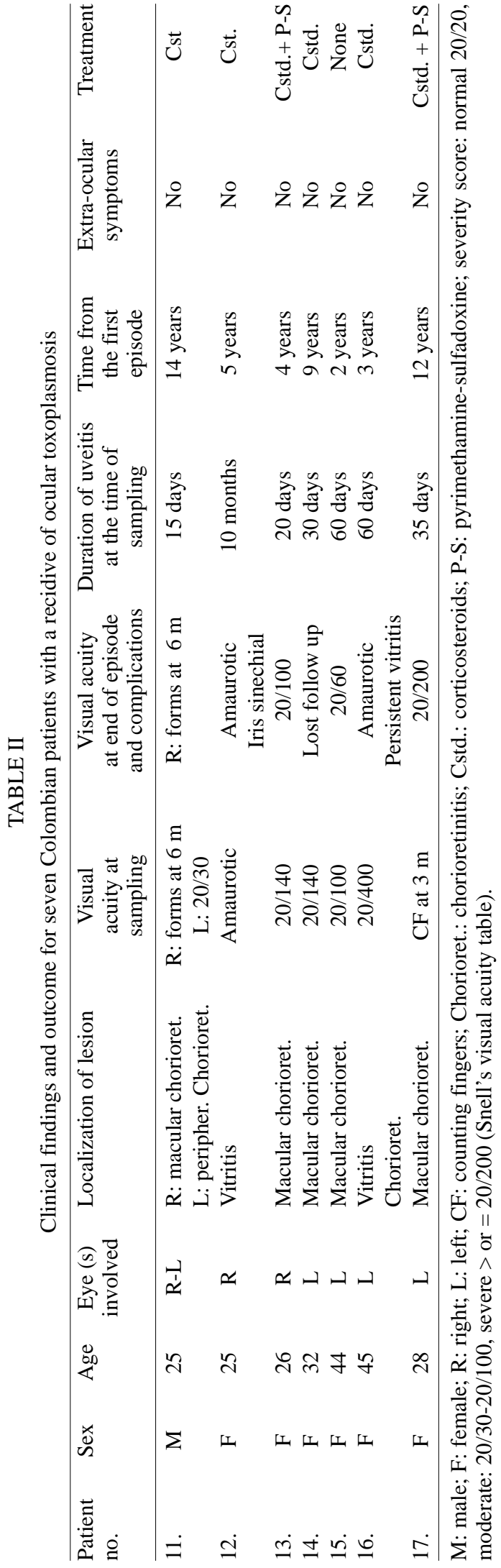

IgE. However, there are cases of reinfection presenting $\operatorname{IgM}$ or $\operatorname{Ig} \mathrm{A}$ alone or even $\operatorname{IgE}$ specific isotypes that have been documented (Fortier et al. 1991, Pinon et al. 1995). But, to our knowledge, there are not reports of simultaneous presence of anti- $T$. gondii specific $\operatorname{IgM}, \operatorname{IgA}$ and $\operatorname{IgE}$ in reinfections. Then, simultaneous presence of IgM, $\operatorname{Ig} \mathrm{A}$ and $\operatorname{IgE}$ can be considered a strong evidence for recent primary infection. If this assumption is true, in our study we found that $1 / 10(10 \%)$ of new cases of ocular toxoplasmosis in Colombian patients from the Quindio region could be related to a recent infection (proportion of cases with specific anti-T. gondii IgM plus IgA plus IgE positive in a first episode). Like Montoya and Remington (1996), we agree that this finding indicates that recent acquired toxoplasmosis is more frequent than believed. Extraocular manifestations of toxoplasmosis were not found in our series. However, in one patient, with an old scar, she stated presence of lymphadenopathies during her first episode of uveitis occurred many years ago. In addition, we have observed in Colombia two other cases with symptoms like fever and adenopathies and serological tests results of recent acquired infection, one of them was a woman who transmitted congenital infection to her offspring (Castaño et al. 1991). This suggests that postnatal acquired toxoplasmosis can produce ocular lesion either accompanied by extraocular symptoms or not. The physiopathological reason for one or the other event remain to be determined. There are similar reports about the frequency of ocular involvement in three outbreaks of recently acquired toxoplasmosis. In an epidemic in Atlanta only one of 37 affected individuals (2.7\%) developed eye disease after four years of follow-up (Akstein et al. 1982). In a well documented family outbreak in New York city, one of seven members (14.2\%) developed toxoplasmic chorioretinitis 129 days after infection (Masur et al. 1978), and in a recent outbreak in British Columbia (Canada) the number of symptomatic patients with ocular toxoplasmosis as clinical presentation was 19 of 100 acute outbreak-related cases (19\%) (Bowie et al. 1997). However, at present we do not have longitudinal studies that establish the exact frequency of toxoplasmic chorioretinitis after postnatal acquired infection and if the frequency of this form can vary from one site to another.

As we stated above, the problem estimating the frequency of postnatal acquired ocular toxoplasmosis based on serological findings, is that it is possible in recurrent cases to find presence of antibodies classically considered to be markers of primary infection. The cases, in the present report, of a recurrence of toxoplasmic chorioretinitis with the presence of specific IgM plus IgA, or IgM plus $\operatorname{IgE}$ in serum, effectively suggest that IgM plus IgA 
TABLE III

Clinical findings and outcome for eleven Colombian patients with chronic inactive ocular toxoplasmosis

\begin{tabular}{|c|c|c|c|c|c|c|c|}
\hline $\begin{array}{l}\text { Patient } \\
\text { no. }\end{array}$ & Sex & Age & $\begin{array}{l}\text { Eye (s) } \\
\text { involved }\end{array}$ & Localization of lesion & $\begin{array}{l}\text { Visual acuity } \\
\text { at at sampling }\end{array}$ & $\begin{array}{l}\text { Time from the } \\
\text { first episode }\end{array}$ & $\begin{array}{r}\text { Extra-ocular } \\
\text { Symptoms } \\
\end{array}$ \\
\hline 18. & M & 17 & $\mathrm{R}$ & $\begin{array}{l}\text { Macular } \\
\text { Scar }\end{array}$ & $20 / 140$ & 2 years & No \\
\hline 19. & $\mathrm{~F}$ & 19 & $\mathrm{R}$ & Peripherical scar & $20 / 20$ & 3 years & Yes \\
\hline 20. & $\mathrm{~F}$ & 28 & $\mathrm{R}$ & Peripherical scar & $20 / 50$ & 2 years & No \\
\hline 21. & M & 33 & $\mathrm{~L}$ & Macular scar & $20 / 200$ & 20 years & No \\
\hline 22. & $\mathrm{~F}$ & 37 & R-L & $\begin{array}{l}\mathrm{R} \text { : perimacular scar } \\
\mathrm{L}: \text { peripherical scar }\end{array}$ & $\begin{array}{l}\mathrm{R}: 20 / 20 \\
\mathrm{~L}: 20 / 20\end{array}$ & $\begin{array}{l}\text { 1st episode: } 6 \text { years } \\
\text { 2nd episode: } 1 \text { year }\end{array}$ & No \\
\hline 23. & M & 38 & $\mathrm{~L}$ & Peripherical scar & $20 / 20$ & Asymptomatic & No \\
\hline 24. & $\mathrm{~F}$ & 20 & $\mathrm{R}$ & Peripherical scar & $20 / 20$ & 5 years & No \\
\hline 25. & $\mathrm{~F}$ & 20 & $\mathrm{R}$ & Peripherical scar & $20 / 30$ & 18 months & No \\
\hline 26. & $\mathrm{~F}$ & 31 & $\mathrm{~L}$ & Peripherical scar & $20 / 400$ & 5 years & No \\
\hline 27. & $\mathrm{~F}$ & 58 & $\mathrm{R}$ & Macular scar & $\mathrm{CF}$ at $3 \mathrm{~m}$ & 20 years & No \\
\hline 28. & M & 54 & $\mathrm{~L}$ & Macular scar & $20 / 20$ & 7 years & No \\
\hline
\end{tabular}

M: male; F: female; R: right; L: left; CF: counting fingers; Chorioret.: chorioretinitis; Cstd.: corticosteroids; P-S: pyrimethamine-sulfadoxine; severity score: normal 20/20, moderate: 20/30-20/100, severe $>$ or $=20 / 200$ (Snell's visual acuity table).

TABLE IV

Serological results for ten Colombian patients with a first episode of ocular toxoplasmosis

\begin{tabular}{lcccc}
\hline $\begin{array}{l}\text { Patient } \\
\text { no. }\end{array}$ & $\begin{array}{c}\text { Inverse titers IgG } \\
\text { IFAT }\end{array}$ & $\begin{array}{c}\text { IgM } \\
\text { IC }\end{array}$ & $\begin{array}{c}\text { IgA } \\
\text { IC }\end{array}$ & $\begin{array}{c}\text { IgE } \\
\text { IC }\end{array}$ \\
\hline 1. & 64 & 8 & 2.5 & 0 \\
2. & 512 & 8 & 0 & 0 \\
3. & 512 & $\mathbf{9}$ & 0 & 0 \\
4. & 128 & 4.5 & 0 & 0 \\
5. & 256 & $\mathbf{1 0}$ & 1.5 & 0 \\
6. & 64 & $\mathbf{1 0}$ & 1.5 & 0 \\
7. & 128 & $\mathbf{1 2}$ & $\mathbf{1 2}$ & $\mathbf{1}$ \\
8. & 128 & 7 & 0 & 0 \\
9. & 512 & $\mathbf{1 0}$ & 0 & 0 \\
10. & 64 & $\mathbf{1 0}$ & 1 & 0 \\
\hline Total positives & & $6 / 10$ & $1 / 10$ & $1 / 10$ \\
& & $(60 \%)$ & $(10 \%)$ & $(10 \%)$ \\
\hline
\end{tabular}

Cutoff values: $\operatorname{IgM}>9, \operatorname{Ig} A>4, \operatorname{IgE}>1$. positive results are shown in bold; IFAT: immunoflourescence antibody test; IC: immunocapture test.

or IgM plus IgE may be present in recurrent clinical episodes. Specific IgA without specific IgM has been reported in a case of reinfection in a French women who had an abortion (Fortier et al. 1991). Similarly, Pinon et al. (1995) described that in a group of HIV-infected patients with evidence of previous exposure to $T$. gondii, but no clinical manifestations, $\operatorname{IgA}$ and IgE were detected in $11 \%$ and $4 \%$ of cases. It would be important to determine if recurrent episodes are due to endogenous reactivation of old infection or to a new reinfection because in this way effective preventive mea-

\section{TABLE V}

Serological results for seven Colombian patients with a recidive of ocular toxoplasmosis

\begin{tabular}{lcccc}
\hline $\begin{array}{l}\text { Patient } \\
\text { no. }\end{array}$ & $\begin{array}{c}\text { Inverse titers IgG } \\
\text { IFAT }\end{array}$ & $\begin{array}{c}\text { IgM } \\
\text { IC }\end{array}$ & $\begin{array}{c}\text { IgA } \\
\text { IC }\end{array}$ & $\begin{array}{c}\text { IgE } \\
\text { IC }\end{array}$ \\
\hline 11. & 64 & $\mathbf{1 1}$ & 0.5 & $\mathbf{2}$ \\
12. & 64 & 0 & 0 & 0 \\
13. & 32 & 6.5 & 0 & 0 \\
14. & 128 & 8.5 & 0.5 & 0 \\
15. & 512 & $\mathbf{9 . 5}$ & $\mathbf{1 1}$ & 0 \\
16. & 128 & 5.5 & 0 & 0 \\
17. & 64 & 4 & 0 & 0 \\
\hline Total positives: & $2 / 7$ & $1 / 7$ & $1 / 7$ \\
& & $(28 \%)$ & $(14.2 \%)$ & $(14.2 \%)$ \\
\hline
\end{tabular}

Cutoff values: $\operatorname{IgM}>9, \operatorname{Ig} A>4, \operatorname{IgE}>1$. positive results are shown in bold; IFAT: immunoflourescence antibody test; IC: immunocapture test.

sures may vary, like antibiotic prophylaxis in the case of endogenous reactivation or hygiene measures for the case of exogenous reinfection.

We have to learn more about the pathogenesis of ocular toxoplasmosis in order to get better therapeutic and public health measures. It will be important to establish if cases of postnatally acquired toxoplasmosis are due to a clonal related strain. Recently we forwarded some hypotheses concerning this topic (Gomez et al. 1997). Montoya and Remington (1996) suggest that the congenital form of ocular toxoplasmosis have a more guarded prognosis than postnatally acquired toxoplasmosis but we found that ocular toxoplasmosis was compli- 
TABLE VI

Serological results for eleven Colombian patients with chronic inactive ocular toxoplasmosis

\begin{tabular}{lcccc}
\hline $\begin{array}{l}\text { Patient } \\
\text { no. }\end{array}$ & $\begin{array}{c}\text { Inverse titers IgG } \\
\text { IFAT }\end{array}$ & $\begin{array}{c}\text { IgM } \\
\text { IC }\end{array}$ & $\begin{array}{c}\text { IgA } \\
\text { IC }\end{array}$ & $\begin{array}{c}\text { IgE } \\
\text { IC }\end{array}$ \\
\hline 18. & 64 & 4 & 0 & 0 \\
19. & 64 & 4.5 & 0 & 0 \\
20. & 64 & 7 & 0 & 0 \\
21. & 128 & 5.5 & 0 & 0 \\
22. & 64 & 5.5 & 4.5 & 0 \\
23. & 8 & 8 & 4 & ND \\
24. & 16 & 4.5 & 0 & 0 \\
25. & 64 & 8 & 0 & 0 \\
26. & 64 & 8.5 & 1 & 0 \\
27. & 8 & 8.5 & 0 & 0 \\
28. & 8 & 7.5 & 0.5 & 0 \\
\hline Total positives & & $0 / 11$ & $2 / 11$ & $0 / 10$ \\
& & $(0 \%)$ & $(18 \%)$ & $(0 \%)$ \\
\hline
\end{tabular}

Cutoff values: $\operatorname{IgM}>9, \operatorname{Ig} A>4, \operatorname{IgE}>1$; positive results are shown in bold; IFAT: immunoflourescence antibody test, IC: immunocapture test, ND: not done.

cated with a persistent vitritis in our patient with serological evidence of recently acquired toxoplasmosis. The study of Ronday et al. (1995) also found severe complications in six of eigth patients with presumed acquired ocular toxoplasmosis. It would be important to test whether Colombian strains of T. gondii are different to strains from other geographical regions and if different strains have different pathogenic properties. In a national survey, $47 \%$ of the Colombian population possessed specific IgG antibodies indicating a high exposition of population to T. gondii (Juliao et al. 1983), but we do not know the real impact of their pathogenic manifestations and studies about the prevalence of ocular toxoplasmosis in the general population are presently going on.

In conclusion, we found that $10 \%$ of patients with a first episode of ocular toxoplasmosis have serological findings of recently acquired infection (simultaneous presence of $\operatorname{IgM}, \operatorname{IgA}$ and $\operatorname{IgE}$ ). During recurrences specific anti-Toxoplasma $\operatorname{IgM} /$ $\operatorname{IgA}$ and $\operatorname{IgM} / \operatorname{IgE}$ were present and $\operatorname{IgA}$ alone was found in chronic setting. We need studies in order to determine the frequency of acquired ocular toxoplasmosis, if the reinfections can trigger recurrences (i.e. in the Colombian cases of recurrence with presence of $\operatorname{IgM}$ and $\operatorname{IgA}$ or $\operatorname{IgM}$ and $\operatorname{IgE}$ in serum) and the impact of strain diversity in the ocular presentation of human toxoplasmosis.

\section{ACKNOWLEDGEMENT}

To Erik Pisano for excellent technical assistance. To Jenny Sant for english revision of the manuscript.

\section{REFERENCES}

Akstein RB, Wilson LA, Teutsch SM 1982. Acquired toxoplasmosis. Opthalmology 89: 1299-1302.

Bowie WR, King AS, Werker DH, Isaac-Renton JL, Bell A, Eng SB, Marion SA 1997. Outbreak of toxoplasmosis associated with municipal drinking water. Lancet 350: 173-177.

Castaño JC, Gómez JE, Duque AM 1991. Toxoplasmosis ocular en el Quindio: características clínicas. Biomédica 11 (Suppl. 1): 121

Frenkel JK 1990. Transmission of toxoplasmosis and the role of immunity in limiting transmission and illness. J Am Vet Med Acad 96: 233-240.

Fortier B, Aissi E, Ajana F, Dieusart P, Denis P, Martin De-Lasalle E, Lecomte-Hocke M, Vinatier D 1991. Spontaneous abortion and reinfection by Toxoplasma gondii (letter). Lancet 338: 444.

Gómez-Marín JE, Pinon JM, Bonhomme A, Guenounou M 1997. Does human toxoplasmosis involves an imbalance in T1/T2 cytokines? Med Hypotheses 48: 161-169.

Henderly DE, Gentsler AJ, Smith RE, Rao NA 1987. Changing patterns of uveitis. Am J Opthalmol 103: 131-36.

Holland GN, O'Connor GR, Belfort Jr R, Remington JS 1996. Toxoplasmosis. In JS Pepose, GN Holland \& KR Wilhelmus (eds), Ocular Infection and Immunity, Mosby Yearbook, St Louis, p. 1183-223.

Instituto Nacional de Salud 1981. Manual de Tecnicas de Laboratorio, Imprenta Ministerio de Salud de Colombia, Bogota, p. 112-118.

Juliao O, Corredor A, Moreno GS 1983. Toxoplasmosis en Colombia, Imprenta Instituto Nacional de Salud, Bogota, p. 67.

Masur H, Jones TC, Lempert JA, Cherubini TD 1978. Outbreak of toxoplasmosis in a family and documentation of acquired retinochoroiditis. Am J Med 64: 396-402.

Montoya JG, Remington JS 1996. Toxoplasmic chorioretinitis in the setting of acute acquired toxoplasmosis. Clin Infect Dis 23: 277-282.

Nussenblatt RB, Belfort R 1994. Ocular toxoplasmosis: an old disease revisited. JAMA 271: 304-307.

Pinon JM, Foudrinier F, Mougeot G, Marx C, Aubert D, Toupance O, Niel G, Danis M, Camerlinck P, Remy G, Frottier J, Jolly D, Bessieres MH, Richard-Lenoble D, Bonhomme A 1995. Evaluation of risk and diagnostic value of quantitative assays for anti-Toxoplasma gondii immunoglobulin A (IgA), IgE, and IgM and analytical study of specific IgG in immunodeficient patients. J Clin Microbiol 33: 878-884.

Remington JS, McLeod R, Desmonts G 1995. Toxoplasmosis. In JS Remington \& JO Klein (eds), Infectious Diseases of the Fetus and Newborn Infant, 4th ed., WB Saunders, Philadelphia, p. 140-267.

Ronday MJ, Luyendijk L, Baarsma S, Bollemeijer JG, van der Lelij, Rothova A 1995. Presumed acquired ocular toxoplasmosis. Arch Opthalmol 113: 1524-1529.

Rothova A, Suttorp-van-Schulten MSA, Fritts W, Kijsltra A 1996. Causes and frequency of blindness in patients with intraocular inflammatory disease. $\mathrm{Br} J$ Opthalmol 80: 332-336.

Varela H, 1986. Uveitis. In F Chalem, N Escandon, A Campos \& I Esguerra (eds), Medicina Interna, Editorial Norma, Bogota, p. 1081-1085. 